\title{
GAMBARAN NILAI BUDAYA ANTARA GENERASI TUA DAN GENERASI MUDA PADA MASYARAKAT TIONGHOA BERAGAMA KONGHUCU
}

\author{
Hertha Christabelle Hambalie ${ }^{1}$ dan Fransisca Iriani R. Dewi ${ }^{2}$ \\ ${ }^{1}$ Fakultas Psikologi, Universitas Tarumanagara \\ Email: hertha_ch@yahoo.co.id \\ ${ }^{2}$ Fakultas Psikologi, Universitas Tarumanagara \\ Email: fransiscar@fpsi.untar.ac.id
}

\begin{abstract}
ABSTRAK
Nilai budaya mengalami perubahan dengan adanya modernisasi dan nilai-nilai baru, tidak terkecuali nilai budaya pada masyarakat Tionghoa di Indonesia. Nilai budaya didefinisikan sebagai ide abstrak yang menjadi pedoman tingkah laku individu dalam masyarakat tertentu. Penelitian ini menggambarkan bagaimana nilai budaya pada masyarakat Tionghoa dengan menggunakan menggunakan mix method, sequential explanatory design. Pertama, peneliti menggunakan metode kuantitatif untuk mendapatkan gambaran umum apakah terdapat perbedaan nilai budaya antara generasi tua dan generasi muda, yang kemudian diperdalam dengan metode kualitatif untuk mendapatkan gambaran lebih rinci bagaimana penerapan nilai budaya. Penelitian ini menggunakan alat ukur Chinese Culture Value (CVS) yang dibuat oleh Bond, dengan jumlah partisipan 62 orang, terdiri dari 31 orang tua yang mewakili generasi tua dan 31 orang anak yang mewakili generasi muda. Berdasarkan hasil analisis kuantitatif dipilih 3 orang tua dan 3 orang anak dengan kategori nilai budaya (1) orang tua rendah dan anak tinggi, (2) orang tua tinggi dan anak tinggi, dan (3) orang tua tinggi dan anak sedang. 6 orang subjek diwawancara dengan wawancara semi-terstuktur. Berdasarkan analisis kuantitatif, diketahui tidak ada perbedaan nilai budaya Tionghoa antara generasi tua dan generasi muda, namun berdasarkan analisis kualitatif, ada perbedaan dalam cara penerapan nilai budaya pada kehidupan sehari-hari.
\end{abstract}

Kata kunci:, nilai budaya, tionghoa, mix method, chinese culture value, konghucu

\section{PENDAHULUAN}

\section{Latar Belakang}

Nilai budaya (culture value) merupakan pedoman perilaku bagi seseorang di masyarakat. Sebagaimana yang dinyatakan Alo (2005), nilai merupakan suatu referensi atau rujukan yang dipegang sebagai pedoman tingkah laku setiap anggota masyarakat atau kelompok budaya tertentu. Nilai merupakan motivasi tingkah laku individu yang menuntun ke tujuan yang dinginkan. Nilai sebagai pedoman berperilaku merupakan hal yang penting pada masyarakat.

Nilai budaya ini mengalami perubahan. Perubahan nilai ini sebagai wujud integrasi nilai modern dengan nilai tradisional (Para Peneliti Dayak, 2017). Namun, perubahan nilai budaya dapat pula terjadi karena adanya pemaksaan nilai-nilai baru dalam kehidupan masyarakat. Padahal tidak semua nilai tradisional buruk dan harus dihindari, sebaliknya justru nilai tradisional itu harus digali dan digunakan untuk mendukung dan membangun agar tidak bertentangan dengan nilai modern (Sutardi, 2007).

Perubahan nilai budaya salah satunya terjadi pada masyarakat Tionghoa. Dewasa ini masyarakat Tionghoa memiliki kecenderungan merupakan budaya psikis (non-material) mereka dan beranggapan bahwa budaya yang mereka miliki tidak lagi sesuai dengan keadaan (Kuncono, 2012). Pemahaman budaya Tionghoa semakin berkurang selama tiga puluh tahun terakhir. Adanya Instruksi Presiden No. 14 tahun 1967 berdampak pada tutupnya sekolah Tionghoa, yang mengakibatkan terjadi kevakuman satu generasi dalam pemahaman budaya Tionghoa. Hal ini mengakibatkan tumbuhnya persoalan baru, misalnya rasa bakti terhadap orang tua (budaya menentang orang tua), penipuan dan ketidakjujuran dalam dunia bisnis, pembunuhan akibat harta waris, dan ketimpangan moralitas yang tidak sesuai dengan ciri khas Tionghoa, hilangnya 
solidaritas serta terpecahnya kehidupan harmonis keluarga Tionghoa (Kuncono, 2012). Padahal dalam nilai budaya Tionghoa mengajarkan hidup selaras dengan watak sejati, bersahaja, jujur, dapat dipercaya, dan tidak menyakiti orang lain. Keadaan ini juga didukung dengan masuknya budaya baru (budaya barat).

Berdasarkan paparan sebelumnya, dapat disimpulkan terdapat perubahan nilai-nilai budaya Tionghoa antara generasi tua dan generasi muda. Perubahan ini menimbulkan dampak-dampak negatif seperti ketidakjujuran, kriminalitas, ketimpangan moral, dan terpecahnya harmonisasi keluarga. Mengingat banyaknya dampak negatif dari perubahan nilai budaya Tionghoa membuat penelitian tentang perubahan nilai budaya penting untuk dilakukan. Berdasarkan hal tersebut peneliti ingin membuat penelitian yang membandingan nilai budaya Tionghoa antara generasi tua dan generasi muda.

Nilai budaya Tionghoa berdasar pada ajaran Confucianism (Songhua, 1999). Confucianism didefiniskan sebagai sistem etika, pendidikan, dan kenegarawanan yang diajarkan oleh Confucius dan murid-muridnya, menekankan cinta untuk kemanusiaan, pemujaan leluhur, hormat kepada orang tua, dan harmoni dalam pikiran dan perilaku. Di Indonesia, ajaran Konghucu menjadi sebuah agama, yakni agama Konghucu. Agama Konghucu resmi diakui di Indonesia pada tanggal 18 November 1978 berdasarkan Surat Edaran Menteri Dalam Negeri No. 447/74054/BA.01.2/4683/95 (Tanggok, 2005). Nilai budaya Tionghoa dan agama Konghucu, keduanya berdasarkan pada ajaran Confuciansm, sehingga perubahan nilai budaya orang Tionghoa akan lebih terlihat dilihat pada masyarakat Tionghoa yang beragama Konghucu dibandingkan dengan agama lain. Bagaimanapun agama membawa tingkah laku budaya masing-masing (Djamin, 2007).

Penelitian akan membandingan antara dua generasi, yaitu generasi tua dan generasi muda. Penutupan semua sekolah Tionghoa dan organisasi Tionghoa pada tahun 1965 memunculkan asumsi berkurangnya penanaman nilai budaya Tionghoa. Di samping penutupan sekolah, penggunaan aksara Tionghoa di tempat umum, pengimporan penerbitan dalam bahasa Tionghoa, dan semua bentuk serta pengungkapan yang dapat ditelusuri asal-usul kebudayaan Tionghoa, seperti perayaan Tahun Baru Imlek dilarang (Dawis, 2010). Di sisi lain pada tahun 2000, larangan bagi WNI keturunan Cina untuk melakukan perayaan pesta agama dan adat istiadat Cina dihapuskan (Tanggok, 2005). Keadaan ini menimbulkan perbedaan pada generasi sekitar tahun 1960 dengan generasi sekitar tahun 2000 (Tanggok, 2005). Perbedaan ini juga ditambah dengan modernisasi yang sekarang ini makin lama makin berkembang.

Penelitian tentang perbedaan nilai antar generasi pernah dilakukan di China, studi yang di lakukan di Shanghai. Penelitian ini membandingkan antara nilai-nilai tradisional dengan nilai-nilai modern yang pegang antar generasi. Hasil penelitian ini menunjukkan terdapat perbedaan nilai yang signifikan antar generasi di China. Berdasarkan penelitian ini dapat diketahui generasi muda lebih memegang nilai modern dibandingan dengan nilai tradisional (Sun \& Wang, 2010).

Berdasarkan paparan di atas, penulis menyimpulkan perubahan nilai budaya karena perubahan keadaan sosial dalam masyarakat serta didukung oleh modernisasi yang sekarang terjadi. Salah satu nilai budaya yang berubah adalah nilai budaya Tionghoa. Perubahan nilai budaya Tionghoa akan mengakibatkan pertentangan, ketidakjujuran, kriminalitas, ketimpangan moral, dan terpecahnya harmonisasi keluarga. Penulis ingin mengetahui lebih lanjut perubahan nilai budaya Tionghoa beragama Konghucu yang akan dilihat melalui perbandingan antar generasi. 


\section{Nilai Budaya}

Berdasarkan Matsumoto dan Juang (2013), nilai budaya (culture value) termasuk dalam satu unsur subjective element dalam kebudayaan. Subjective element adalah semua bagian kebudayaan yang tidak bertahan sebagai artefak fisik. Jadi, termasuk proses psikologis, seperti value (nilai), beliefs, norm, attitudes, dan worldviews. Nilai adalah prinsip yang menuntun ke tujuan yang dinginkan yang menjadi motivasi tingkah laku. Nilai menetapkan moral, politik, sosial, ekonomi, estetika, atau etika spiritual seseorang atau kelompok. Nilai ada pada dua level yaitu nilai personal dan nilai budaya. Nilai personal merepresentasikan peralihan tujuan yang diinginkan yang tersaji sebagai prinsip yang menuntun kehidupan seseorang. Nilai budaya dibagi, ide abstrak tentang pandangan kolektif kelompok sebagai hal yang baik, benar, dan diinginkan.

Pernyataan di atas juga didukung Alo (2002), di mana semua masyarakat di dunia memiliki kebudayaan, salah satu komponen kebudayaan adalah nilai. Nilai merupakan suatu referensi atau rujukan yang dipegang sebagai pedoman tingkah laku setiap anggota masyarakat atau kelompok budaya tertentu (Alo, 2002). Nilai budaya dalam Kamus Besar Bahasa Indonesia (KBBI) diartikan sebagai konsep abstrak mengenai masalah dasar yang sangat penting dan bernilai di kehidupan manusia. Berdasarkan beberapa pengertian tersebut, disimpulkan bahwa nilai budaya adalah ide abstrak yang menjadi pedoman tingkah laku individu dalam masyarakat tertentu dan merupakan hal yang penting dalam masyarakat.

\section{Tionghoa}

Berdasarkan Onghokham (2009), orang Tionghoa (tidak dilihat dari hukum kewarganegaraan) terbagi dalam dua kategori, yakni Tionghoa totok dan Tionghoa peranakan. Tionghoa totok adalah mereka yang lahir di Tiongkok. Walaupun sudah lama tinggal di Indonesia, tidak lagi menggunakan bahasa Tionghoa dan adat istiadat yang dilakukan tidak sepenuhnya Tionghoa, mereka tetap disebut orang Tionghoa. Hal tersebut adalah hasil dari akultutasi. Berbeda dengan Tionghoa totok, Tionghoa peranakan adalah orang Tionghoa yang lahir di Indonesia. Dapat disimpulkan Orang Tionghoa adalah orang yang lahir di Indonesia atau lahir di Tiongkok dan sudah lama tinggal di Indonesia.

Orang Indonesia Tionghoa hidup dalam keadaan sosial, politik, dan sejarah yang rumit selama beberapa generasi. Berdasarkan Copel (2002), selama zaman penjajahan, Bangsa Belanda membangun kekaisaran Hindia Baru mereka berdasarkan "devide et impera", yang melahirkan ras tripatrit. Menurut sistem ini, bangsa Eropa ditempatkan di jejaring sosial paling atas, sedangkan orang asing dari Asia (orang Tionghoa) dan penduduk asli (pribumi Indonesia) ditempatkan pada urutan bawahnya. Pengaturan ini dirancang untuk memisahkan orang Tionghoa dari penduduk pribumi, dan mengadu domba kedua kelompok ini. Akibatnya terjadi pembantaian orang Tionghoa di Jawa pada tahun 1740. Malangnya, meskipun terjadi pembantaian ini dan berbagai larangan yang dikenakan terhadap orang Tionghoa untuk masuk dan keluar kompleks tempat tinggal mereka, sebagian besar penduduk pribumi masih membenci orang Tionghoa karena "kedudukan lebih tinggi" yang mereka miliki.

Bergeraknya Indonesia ke arah demokrasi konstitusi sesudah proklamasi kemerdekaan di negeri ini dari kekuasaan Belanda pada 17 Agustus 1945. Di bawah pimpinan Soekarno, presiden pertama Indonesia, sadar akan masalah yang dihadapi orang Tionghoa mengenai kewarganegaraan mereka. Perundingan Meja Bundar, menentapkan nyaris semua orang Tionghoa yang lahir di Indonesia diberikan kebebasan untuk memilih kewarganegaraan. Mereka dapat secara otomatis memperoleh kewarganegaraan Indonesia atau menetapkan status mereka sebagai warga Negara Tiongkok dengan secara resmi menolak kewarganegaraan Indonesia dalam waktu dua tahun (1949-1951). 
Kesulitan muncul karena ada peluang untuk memiliki kewarganegaraan tunggal, keadaan ini melahirkan Perjanjian Kewarganegaraan Ganda tahun 1955 oleh pemerintah Indonesia dan pemerintah Tiongkok. Warga Negara Asing (WNA), yang berarti orang asing Tionghoa Indonesia, digunakan untuk membedakan mereka dari orang pribumi setiap kali mereka membutuhkan surat izin dari pemerintah, fasilitas kredit, surat izin mengimpor atau memproduksi barang, memeroleh hak jual grosir, dan melakukan transaksi mata uang asing.

Menurut Copel (1976), diskriminasi yang semakin meluas terhadap orang Tionghoa baik asing maupun warga Negara Indonesia terjadi pada bidang politik. Ketika Indonesia memasuki masa guncangan politik dan krisis pada tahun 1965, semua organisasi Tionghoa, termasuk Badan Permusyawaratan Kewarganegaraan Indonesia dan semua sekolah Tionghoa, ditutup. Pada tahun 1965 Suharto mulai berkuasa sesudah upaya kudeta yang digagalakan (dikenal dengan sebutan gerakan 30 September atau G30S atau Gestapu) yang ditengarai oleh PKI. Di masa sesudah upaya kudeta tersebut, pecah kerusuhan anti-Tionghoa di kota-kota besar di Indonesia.

\section{Konghucu}

Suryadinata (2010) menyatakan bahwa pada awal abad 20, agama dari masyarakat Tionghoa di Indonesia pada dasarnya terbentuk dari aliran, terdiri dari Buddhism, ajaran Confucian (di mana merupakan filosofi asli dari Elit politis China dan karenanya tidak dimengerti secara baik oleh orang yang tidak berpendidikan), dan Taoism, sebuah kepercayaan rakyat. Seperti kebanyakan agama kuno, sebuah agama polytheistic. Meskipun demikian, setelah kelahiran Indonesia yang modern, masyarakat Tionghoa di Indonesia memeluk suatu agama, terbagi menjadi pengikut Buddha atau agama Konghucu.

Pada permulaan pemerintahan Soeharto agama Konghucu seakan-akan mendapat kemungkinan hidup kembali. Pada pertengahan 1960-an penganuh agama ini membuat suatu dewan agama Konghucu. Walaupun kehadirannya tersendat-sendat, tidak mempunyai lembaga terorganisasi maupun cara-cara upacara keagamaan yang baku, tetapi agama itu bisa bertahan hingga enam kongres yang diadakan pada 1967. Namun hal itu berhenti pada tahun 1979 di mana Instruksi Presiden Soeharto yang mengatakan bahwa jelas-jelas Konghucu bukan agama (Tanggok, 2005). Saat Soeharto berkuasa saat perang dingin terjadi, Indonesia memasuki era histeria anti-china dan China-phobia.

Pro-kontra sebagai status agama Konghucu ini tampaknya akan berakhir setelah pemerintahan Gus Dur mencabut Instruksi Presiden No. 14 tahun 1967 tentang larangan bagi WNI keturunan Cina untuk melakukan perayaan pesta agama dan adat istiadat Cina secara terbuka dan pencabutan atas Surat Edaran Menteri Dalam Negeri No. 447/74054/BA.01.2/4683/95 tanggal 18 November 1978 tentang lima agama yang diakui pemerintah, yaitu: Islam, Kristen Protestan, Katolik, Hindu, dan Buddha (Tanggok, 2005). Di mana kebanyakan umat Konghuchu adalah orang Tionghoa (Suhandinata, 2009).

\section{METODE PENELITIAN}

\section{Partisipan}

Partisipan yang digunakan dalam penelitian ini adalah orang tua $(n=31)$ yang mewakili generasi tua dan anak $(n=31)$ yang mewakili generasi muda. Tionghoa yang beragama Konghucu. Orang tua lahir pada tahun 1952 atau sebelumnya dan anak minimal lahir pada tahun 1982 atau sebelumnya (15 tahun sebelum dan sesudah pembebasan budaya Tionghoa pada tahun 1967). Teknik pemilihan subjek yang digunakan adalah purposive sampling. Kemudian berdasarkan hasil 
kuisioner, akan dipilih subjek (orang tua dan anak) dengan kategori (1) orang tua rendah dan anak tinggi; (2) orang tua tinggi dan anak tinggi; (3) orang tua tinggi dan anak rendah; dan (4) orang tua rendah dan anak rendah. Namun pada penelitian ini kategori (3) tidak terjadi sehingga digantikan dengan orang tua tinggi dan anak sedang. Kategori (4) tidak memungkinkan untuk diwawancarai dengan alasan kesehatan.

Setting dalam penelitian ini dilakukan di lingkungan tempat tinggal masyarakatyang beragama Konghucu dan di sekitar Lithang, tempat beribadat agama

Konghucu di Depok.

\section{Alat ukur nilai budaya Tionghoa}

Penelitian ini menggunakan kuisioner dengan format sematik deferensial, di mana terdapat 46 pernyataan. Kusioner yang digunakan diadaptasi dari kuisioner The Chinese Value Survey yang dibuat oleh Bond (Matthews, 2000). Kuisioner yang telah diadaptasi oleh penulis menggunakan skala dari 1 sampai dengan lima. Skala 1 menyatakan pernyataan tersebut sangat penting, skala 2 menyatakan pernyataan tersebut kurang penting, skala 3 menyatakan pernyataan tersebut tidak penting, skala 4 menyatakan pernyataan tersebut penting, dan skala 5 menyatakan pernyataan tersebut sangat penting. Reabilitas The Chinese Value Survey pada penelitian ini 0.919 (alpha cronbach) dengan butir gugur 44 dan 19

\section{Prosedur}

Penelitian ini menggunakan mix method, penggabungan antara metode kuantitatif dan kualitatif. Pertama, peneliti menyebarkan kuisioner kepada seluruh partisipan kemudian peneliti menggunakan analisis uji beda dua kelompok untuk melihat apakah ada perbedaan nilai budaya antara generasi tua dan generasi muda. Kedua, peneliti menggunakan metode kualitatif. Teknik yang digunakan adalah wawancara semi terstuktur dan observasi. Teknik ini digunakan untuk memeriksa kembali dan menggeksplorasi bagaimana penerapan aspek-aspek dalam nilai budaya yang dipengang oleh setiap subjek. Penerapan nilai budaya subjek dilihat dan dibandingkan antara generasi tua dan generasi muda.

\section{HASIL \& PEMBAHASAN}

Berdasarkan analisis data kuantitatif diketahui gambaran umum nilai budaya dan adakah perbedaan nilai budaya antara generasi tua dan generasi muda. Skor rata-rata nilai budaya kelompok generasi tua 4.2324, sedangkan skor nilai budaya kelompok generasi muda 4.1833. Berdasarkan hasil skor nilai budaya kelompok generasi tua memiliki nilai budaya lebih tinggi 0.0491. Standar Deviasi untuk kelompok generasi tua adalah 0.3565 dan untuk kelompok generasi muda 0.29667. Standar Error Mean adalah 0.06028 untuk orang tua dan 0.05328 untuk anak.

Berdasarkan uji perbedaan dua kelompok, tidak ada perbedaan nilai budaya antara generasi tua dan generasi muda yang signifkan, $F=0.832, p=0.365$. Nilai $p>0.05$. Derajat kebebasan antara generasi tua dan generasi muda juga tidak signifikan pada taraf signifikansi $0.05, \mathrm{t}=6.11, \mathrm{p}>0.05$. Hasil data kemudian diperdalam dengan metode kulitatif.

Analisis kuantitatif ini kemudian diperdalam dengan analisis kualitatif. Analisis kulitatif memberi gambaran nilai budaya pada keenam subjek dan perbandingan nilai budaya antara anak dan orang tua. Gambaran nilai budaya ini meliputi dimensi (a) toleransi dan stabilitas sosial; (b) dinamika Confucian; (c) kebaikan hati; dan (d) kontrol diri. 
Berdasarkan analisis dimensi toleransi dan stabilitas sosial, kedua generasi baik generasi tua dan generasi muda sependapat bahwa perbedaan pendapat dinilai sebagai hal yang positif. Perbedaan antara kedua generasi terlihat pada penerapan toleransi, terutama toleransi dengan teman. Generasi tua dalam menghadapi perbedaan pendapat lebih mencari jalan tengah, sedangkan generasi muda lebih mengikuti orang lain. Perbedaan antar generasi juga terlihat pada usaha menjaga kerukunan. Generasi tua lebih aktif dalam menjaga kerukunan dengan sosialisasi dan mengikuti kegiatan di lingkungan, sedangkan generasi muda lebih bersifat pasif dengan berusaha tidak membuat kesalahan. Hal ini serupa dengan cara membangun rasa percaya, khususnya pada orang baru dan di lingkungan. Generasi tua mau lebih aktif membangun rasa percaya, sedangkan generasi muda lebih memilih bersikap pasif, dengan bersikap apa adanya dan bersikap wajar. Hubungan akrab yang dimiliki generasi tua tidak jauh berbeda dengan generasi muda.

Berdasarkan analisis dimensi dinamika confucian, penerapan hirarki sosial sudah tidak terlalu terlihat, baik pada generasi tua maupun pada generasi muda. Dalam menjalankan tradisi, kedua generasi masih menjalankan tradisi yang tidak jauh berbeda. Keduanya juga perasaan yang sama dalam menjalankan tradisi, yaitu senang dan bangga. Perbedaan yang terlihat antar generasi terletak pada makna dan sejarah tradisi. Generasi muda sudah kurang mengenal sejarah dan makna tradisi dibandingkan dengan generasi dua.Selain hirarki sosial dan tradisi, dinamika confucian juga ditandai dengan keinginan kuat untuk menjaga harga diri (Ralston, Gustavson, Cheung, \& Tersptra, 1993). Dalam menjaga harga diri, kedua generasi memiliki pendapat yang sama, di mana harga diri adalah hal yang penting dan harus dijaga. Generasi muda dan generasi tua memiliki cara yang beragam dalam menjaga harga diri.

Dimensi kebaikan hati, dikarakterikan dengan kebutuhan menjadi baik, memaafkan, dan sopan. Baik generasi tua dan generasi muda berusaha menjadi baik dengan berbagai cara. Kedua generasi memiliki perbedaan alasan mengapa seseorang menjadi baik. Generasi tua menjadi baik karena terdorong dari dalam diri (senang dan kewajiban), sedangkan generasi muda lebih ingin mendapatkan balasan yang baik juga. Hal serupa juga terjadi dalam hal memaafkan. Kedua generasi memiliki alasan berbeda dalam memaafkan. Generasi tua lebih cenderung memaafkan karena ajaran agama, sedangkan generasi muda cenderung karena terdorong oleh rasa empati. Kedua generasi memiliki pengalaman memaafkan dan memiliki penilaian yang sama. Kedua generasi menilai memaafkan adalah sesuatu penting dan tidak perlu menunggu orang lain minta maaf untuk dimaafkan. Dalam hal sopan santun, kedua generasi memiliki persamaan dan perbedaan. Persamaan sopan santun kedua generasi terlihat pada sikap kepada teman dan keluarga. Kedua generasi bersikap lebih santai kepada teman, sedangkan kepada keluarga kedua generasi menyesuaikan kata-kata dengan lawan bicara dan tidak menggunakan elu-gua karena dianggap kasar. Sedangkan perbedaan yang ditunjukkan kedua generasi, terlihat pada sikap kepada orang baru. Generasi tua tetap bersikap sopan walaupun orang tersebut dinilai mencurigakan, sedangkan generasi muda memilih menjaga jarak pada orang yang mencurigakan.

Dimensi kontrol diri dilihat dari berbagai aspek, yaitu budaya, uang, organisasi, penyesuaikan diri, mengontrol dan dikontrol orang lain. Dianalisis dari sisi budaya budaya, generasi muda lebih menilai budaya sendiri lebih baik dibanding budaya orang lain. Namun, kedua generasi sama-sama menilai budaya orang lain juga baik. Sedangkan sedangkan dianalisis dari sisi uang, baik generasi tua dan generasi muda menanggap uang adalah hal yang penting, namun bukan menjadi hal utama, ada hal lain yang lebih penting dibandingkan uang. Pada kegiatan organisasi, generasi tua lebih terlibat dalam kegiatan organisasi dibandingkan generasi muda. Namun dalam hal menyesuaikan diri dengan lingkungan, generasi muda lebih berusaha menyesuaikan diri dibandingkan generasi 
tua. Dalam mengontrol orang lain dan dikontrol kedua generasi dapat mengontrol dan dikontrol orang lain dengan cara berbeda. Jika dibandingkan, generasi tua lebih dapat dikontrol orang lain dibanding generasi muda.

\section{Diskusi}

Hasil penelitian ini berbeda dengan hasil penelitian yang pernah dilakukan di Shanghai, China oleh Sun \& Wang (2010). Hasil penelitian Sun dan Wang (2010) menemukan bahwa generasi muda sudah beralih dari nilai tradisional ke modern. Ada perbedaan yang signifikan antara generasi tua dan generasi muda. Penelitian Sun dan Wang (2010) sendiri memiliki metode yang berbeda dengan penelitian ini. Di sisi lain, hasil penelitian ini didukung temuan penelitian Kurniawati (2015), yang menemukan bahwa meskipun sempat ada larangan dari Orde Baru menjalankan ritual Budaya China, tetap tidak menghalangi masyarakat Tionghoa di Indonesia untuk melakukan pembelajaran budaya sendiri. Berdasarkan Kurniawati (2015), agama dapat menghalangi seseorang untuk menerima budaya. Dalam penelitian ini, subjek penelitian adalah agama Konghucu, sehingga tidak terdapat halangan untuk menjalankan tradisi Tionghoa. Baik generasi tua maupun generasi muda diketahui melakukan tradisi yang tidak jauh berbeda.

Perbedaan dalam tradisi terlihat pada makna dan sejarah tradisi. Generasi muda sudah kurang mengenal sejarah dan makna tradisi dibandingkan dengan generasi tua. Hal ini dikarenakan adanya larangan Orde Baru, yang mengakibatkan penutupan sekolah Tionghoa serta tidak adanya media yang menginformasikan tentang budaya Tionghoa. Dari segi kognitif, tidak adanya infomasi yang diberikan tentang budaya Tionghoa mengakibatkan ketidaktahuan generasi muda tentang sejarah dan makna tradisi. Selain adanya peran lingkungan, keluarga juga memiliki peran yang penting dalam pembelajaran tradisi. Orang tua hanya mengajarkan bagaimana menjalankan tradisi, namun tidak ada pengajaran tentang makna dan sejarah dibalik tradisi. Keadaan lingkungan dan keluarga menyebabkan ketidaktahuan generasi muda akan sejarah dan makna dari tradisi.

Selain tradisi, perbedaan-perbedaan penerapan nilai budaya lain juga dipengaruhi adanya akulturasi. Akulturasi menurut Koentjaraningrat, percampuran menyangkut konsep mengenai proses sosial yang timbul jika sekelompok manusia dengan suatu kebudayaan tertentu dihadapkan dengan kebudayaan asing (Sutardi, 2007). Di Indonesia sendiri kebudayaan Tionghoa banyak dihadapkan oleh kebudayaan-kebudayaan lokal selama beberapa beberapa generasi, yang tidak menutup kemungkinan mempengaruhi nilai budaya Tionghoa. Teknologi yang sekarang ini semakin berkembang membuat budaya-budaya lain, seperti budaya barat mudah masuk ke dalam masyarakat. Generasi muda sangat rentan terhadap pengaruh budaya asing (Sutardi, 2007).

Perbedaan-perbedaan antar generasi juga terjadi karena perubahan lingkungan. Perbedaan dalam sopan santun pada orang baru, misalnya. Generasi muda lebih memilih menjaga jarak pada orang yang mencurikan, sedangkan generasi tua tetap berusaha sopan. Lingkungan di mana generasi muda tumbuh dan belajar memiliki tingkat kriminalitas yang tinggi dibandingan generasi tua. Adanya perubahan lingkungan mempengaruhi pola pikir dan persepsi seseorang menilai dunia dan lingkungannya (Santrock, 2003).

Penelitian ini memiliki beberapa keterbatasan. Keterbatasan yang pertama, teori dasar nilai budaya Tionghoa (chinese culture value) memiliki teori dasar yang sedikit sehingga penulis memakai sumber lain untuk memberikan definisi beberapa kata untuk melengkapi teori dasar. Keterbatasan yang kedua, penelitian ini tidak mendapatkan satu kategori subjek, yakni anak rendah dan orang tua rendah, karena alasan kesehatan. Hal ini tidak mempengaruhi hasil penelitian, namun untuk perbandingan antar generasi menjadi kurang lengkap. 
Peneliti secara tidak sengaja melakukan wawancara dengan dua dari tiga orang tua yang merupakan rohaniwan. Namun kedua orang tua berasal dari kelompok kategori berbeda, di mana satu orang berasal dari kategori nilai budaya tinggi dan yang lainnya berasal dari kategori nilai budaya rendah. Berbedanya kategori subjek rohaniwan membuat hasil penelitian tidak terlalu terpengaruh.

\section{KESIMPULAN DAN SARAN}

Tidak ada perbedaan nilai budaya antara generasi tua dan generasi muda, namun ada perbedaan dalam menerapkan nilai budaya di masyarakat antara generasi tua dan generasi muda. Saran kepada penelitian selanjutnya untuk mengambil subjek dari berbagai agama untuk melihat nilai budaya dari sisi subjek dengan agama yang berbeda. Bagi masyarakat Tionghoa kiranya masyarakat Tionghoa lebih menyadari dan mengali lebih dalam nilai-nilai Tionghoa, terutama nilai-nilai yang sudah mulai mengalami perubahan. Bagi lembaga pendidikan, baik sekolah (khususnya sekolah Tionghoa) ataupun lembaga pendidikan agama Konghucu agar memberikan pengajaran yang menanamkan kembali nilai budaya yang sudah mulai luntur pada generasi muda.

\section{Ucapan Terima Kasih (Acknowledgement)}

Peneliti mengucapkan terima kasih kepada seluruh partisipan yang sudah bersedia berpartisipasi dalam penelitian kali ini dan pihak-pihak yang telah membantu dalam penyusunan artikel ini.

\section{REFERENSI}

Chan, A. M. (2009). Measuring cross-cultural values: a qualitative approach. International Review of Business Research Papers, 5(6), 322-337. Retrieved from https://pdfs.semanticscholar.org/

Dawis, A. (2010). Orang indonesia tionghoa mencari identitas. Jakarta: Gramedia Pustakan Utama.

Djamin, D. (2007). Pengawasan dan pelaksanaan undang-undang lingkungan hidup: suatu analisis sosial (1st ed.). Jakarta: Yayasan Obor.

Inglehart, R., \& Welzel, C. (2005). Modernization, cultural change and democracy [Modernization, cultural change and democracy]. Retrieved from https://books.google.co.id/books?id=O3VBq2rVRJMC\&printsec=frontcover\&dq=Moderni zation,+cultural+change+and+democracy\&hl=en\&sa=X\&ved=0ahUKEwib09SwxILaAhV FqI8KHWgQD7wQ6AEIKTAA\#v=onepage\&q=Modernization\%2C\%20cultural\%20chan ge $\% 20$ and $\% 20$ democracy $\& \mathrm{f}=$ false

Kuncono, O. S. (2012). Nilai-nilai positif budaya Tionghoa. Study Park of Confucius. Retrieved from http://www.spocjournal.com/budaya/82-nilai-nilai-positif-budaya-tionghoa.html

Kurniawati, M. (2015). How to transfer culture integration (case study in chinese Indonesia (Tionghoa). International Review of Social Scienes, 3(6), 231-235.

Matsumoto, D. R., \& Juang, L. P. (2013). Culture and psychology (5th ed.). Boston. MA: Wadsworth Cengage Learning. Retrived from https://www.researchgate.net/publication/232491492_Culture_and_psychology_3rd_ed.

Matthews, B. M. (2000). The Chinese value survey: an interpretation of value scale and consideration of some preliminary result. International Education Journal, 1(2), 117-125. 
Retrieved from https://ehlt.flinders.edu.au/education/iej/articles/v1n2/MATTHEWS/MATTHEWS.pdf.

Para Peneliti Dayak. (2017). Kebudayaan Dayak. Retrieved from https://books.google.co.id/books?id=rNUtDwAAQBAJ\&pg=PA86\&dq=perubahan+nilai+ budaya\&hl=en\&sa=X\&ved=0ahUKEwituYr64s3ZAhXLOI8KHUABDGQQ6AEIWDAH $\# \mathrm{v}=$ onepage $\& \mathrm{q}=$ perubahan\%20nilai\%20budaya $\& \mathrm{f}=$ false.

Ralston, D. A., Gustafson, D. J., Cheung, F. M., \& Terpstra, R. H. (1993). Differences in managerial values: a study of U.S., Hong Kong and PRC managers. Journal of International Business Studies, 24(2), 249-275. Retrieved from https://link.springer.com/article/10.1057/palgrave.jibs.8490232.

Santrock, J. W. (2013). Adolescence (6th ed.). London, LCY: Mcgraw Hill.

Songhua, F. (1999). The modern significance of Chinese traditional culture. The Bases of Value in a Time of Change: Chinese and Western, 16(3), 283-290. doi: 10.2307/2644682.

Suhandinata, J. (2009). WNI Keturunan Tionghoa dalam stabilitas ekonomi dan politik Indonesia. Jakarta: Gramedia Pustaka Utama.

Sun, J. \& Wang, X. (2010). Value differences between generation in China: study in Shanghai. Journal of Youth Studies, 13 (1), 65-81. Doi: 10.1080/13676260903173462

Suryadinata, L. (2010). Etnis Tionghoa dan nasionalisme Indonesia. Jakarta: Kompas Media Nusantara.

Sutardi, T. (2007). Antropologi mengungkapkan keragaman budaya. Bandung: Setia Purna Inves.

Tan, M. G. (2008). Etnis Tionghoa di Indonesia - Kumpulan tulisan. Jakarta: Yayasan Obor Indonesia.

Tanggok, M. I. (2005). Mengenal lebih dekat "agama Konghucu” di Indonesia. Jakarta: Pelita Kebajikan. 